\title{
Population genetic structure and demographic history of the freshwater crab Potamon elbursi (Brachyura: Potamidae) from the Alborz Mountains in northern Iran
}

\author{
Alireza KEIKHOSRAVI, ${ }^{1,2^{*}}$ Sara FRATINI, ${ }^{3}$ Christoph D. SCHUBART ${ }^{1}$ \\ ${ }^{1}$ Zoology \& Evolutionary Biology, Universität Regensburg, D-93040 Regensburg, Germany; ${ }^{2}$ Department of Biology, Faculty of \\ Science, Hakim Sabzevari University, Sabzevar, Iran; ${ }^{3}$ Department of Biology, University of Florence, via Madonna del Piano 6 , \\ 50019 Sesto Fiorentino (FI), Italy \\ *Corresponding author: A.Keikhosravi@hsu.ac.ir
}

\begin{abstract}
Hydrographically separated populations of the freshwater crab Potamon elbursi Pretzmann, 1976 were genetically investigated to assess their local diversity and to reconstruct the possible role of Quaternary glaciations in shaping current diversity in the Alborz Mountains, northern Iran. A total of 61 specimens from six rivers were collected from the two different drainage systems of the Alborz Mountains, Namak Lake and the South Caspian watershed. A comparative analysis of a partial sequence of the mitochondrial cytochrome oxidase subunit I gene revealed relatively high overall haplotype diversity and low nucleotide diversity. In four populations, there is no association between the haplotype network and the geographical separation between drainages, whereas the remaining two populations consist of private haplotypes. Gene flow among rivers was estimated using pairwise differences of Фst; in almost all cases gene flow was significantly restricted, regardless of association to a particular river system. Surprisingly, the only exception was the pairwise comparison of two distant rivers belonging to different drainages; this lack of differentiation may be attributed to incomplete lineage sorting or secondary introduction events. The mismatch distribution analysis, together with the shape of the haplotype network and the nucleotide and haplotype diversity indices, indicates that the studied metapopulation shows the signature of recent population bottlenecks followed by demographic or spatial expansion dating back to Pleistocene climatic fluctuations.
\end{abstract}

Key words: Cox1 gene, phylogeography, conservation, Namak Lake, Caspian Sea.

Received: April 2014. Accepted: March 2015.

\section{INTRODUCTION}

Phylogeographical patterns reconstructed from present genetic data can provide insight into the processes generating biological diversity, and such diversity can be dramatically affected by Pleistocene glacial cycles (Avise, 2000; Hewitt, 2000). The Pleistocene climate of Iran was more distinctive than in other countries at similar latitudes (Krinsley, 1968) and exerted great influence on the biota of Iran. The Pleistocene climatic fluctuations created many ice barriers and blocked connections between populations of freshwater fauna in the Alborz Mountains (Banarescu, 1991; Brandis et al., 2000). This, for example, explains the occurrence of a freshwater crab species, Potamon bilobatum Brandis, Storch \& Türkay 2000, with a highly confined local distribution in this region. The fragmented distribution of the lizard genus Iranolacerta, present in the northwest of Iran and the central Zagros Mountains, is also most likely due to past climatic fluctuations (Ahmadzadeh et al., 2012). Rajaei Sh et al. (2013) discuss the occurrence of two sympatric moth species whose populations were contracted into several possible refugia (especially the Zagrosians) during the
Last Glacial Maximum, suggesting a noticeable effect of glacial periods. So far, no study has been conducted on the effect of glacial periods on population structure of freshwater organisms in the Alborz Mountains. Therefore, it seems necessary to study the possible role of Pleistocene glaciations on the phylogeographical patterns of freshwater organisms.

The Middle East is one of the main distribution areas for freshwater crabs of the genus Potamon Savigny, 1816. Recently, Keikhosravi and Schubart (2014) re-described and revalidated Potamon elbursi Pretzmann, 1976, confirming its status as an endemic species of northern Iran. The distribution of this species is bordered to the north by the central and southern slopes of the western Alborz Mountains, whereas the southernmost distribution reaches to the sources of two drainage systems, Namak Lake and the South Caspian Sea drainages. Only at one point does the distribution extend northward through the Alborz Mountains (Sepidrood Valley), reaching the Caspian Sea (Fig. 1). P. elbursi thrives over a large range of climatic zones; therefore obtaining knowledge about the population genetic structure of this species will facilitate a better understanding of its biology and diversification patterns to avoid repetition. 
It will also aid conservation efforts if necessary, which may become important, as some unique and endemic co-occurring freshwater fish species of the southern Caspian Basin are critically endangered (Kiabi, 1999; Coad, 1980). Worldwide, about one-sixth of all freshwater crab species are at an elevated risk of extinction as a result of anthropogenic environmental impacts (Cumberlidge et al., 2009).

In the present study, we sequenced a portion of the mitochondrial DNA cytochrome oxidase subunit I (mtDNA Cox1) of 61 individuals of $P$. elbursi belonging to six populations from the central Alborz Mountains in order to i) estimate genetic diversity at inter- and intra-population level while reconstructing population structure; and ii) to determine the likely impact of Pleistocene glaciations on the population structure of $P$. elbursi, while proposing a historical demography. Our hypothesis, based on reproductive biology and limited dispersion ability of the species, is that there is a genetic partition in this species, with populations belonging to different drainages being more different than populations living in the same drainage. Moreover, we hypothesize that the studied metapopulation will carry a signature of population bottleneck followed by expansion, due to recent glaciations, as reported for other species of this area.

\section{METHODS}

\section{Sampling strategy and laboratory work}

The Alborz Mountains extend from the northwest of Iran to the southern shores of the Caspian Sea and stretch to the borders of Turkmenistan in the northeast (Fig. 1). Two distinct climate zones can be encountered on each side of the mountain chain: the northern slopes face the lowland area of the Caspian region, a highly forested

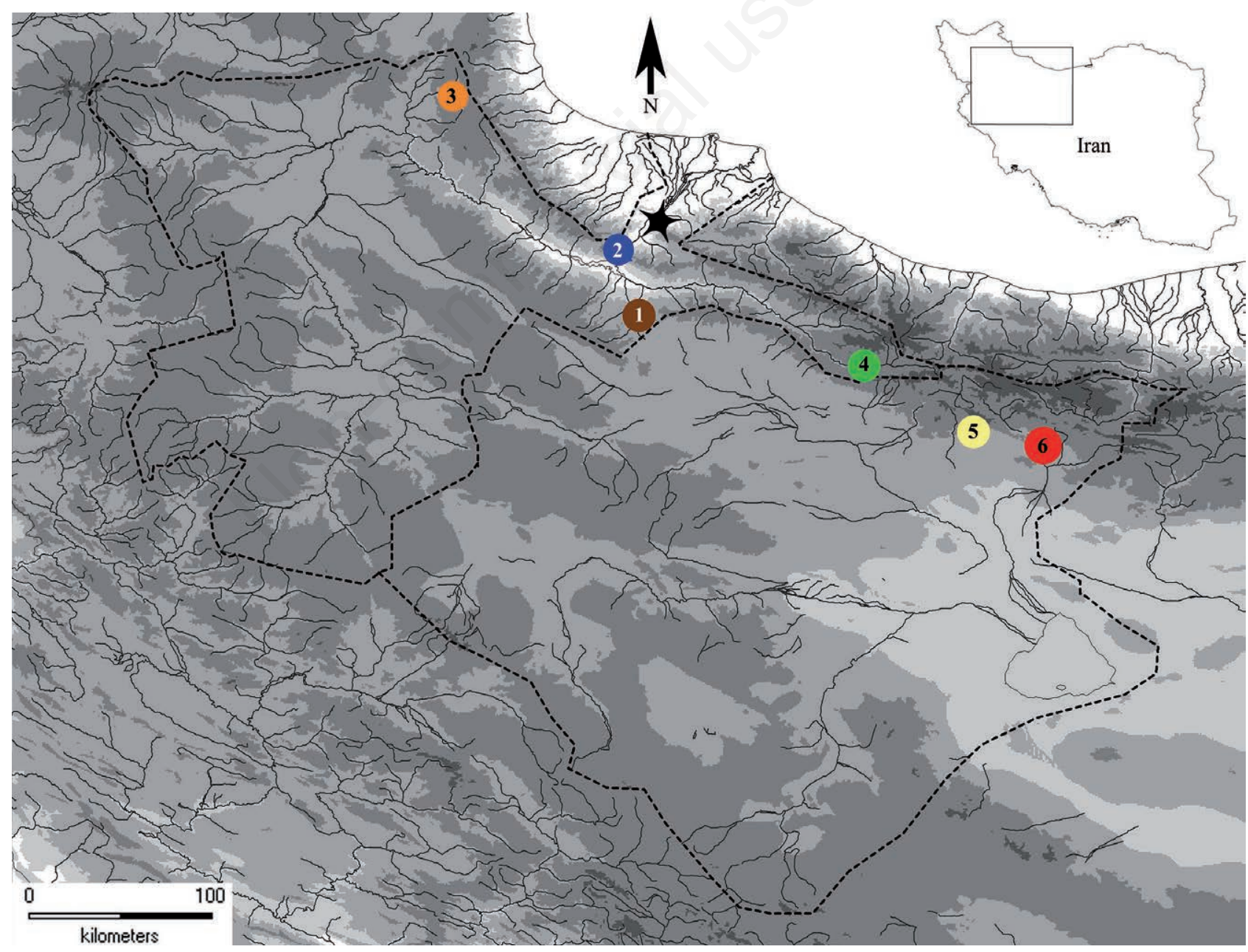

Fig. 1. Distribution of Potamon elbursi in two drainage systems encircled by dashed lines: Namak Lake system (right) and South Caspian Sea system (left). Asterisk indicates the location of the Sepidrood Valley. Higher Alborz elevations are indicated by increasing gray shades. Encircled numbers show the localities of collection of selected populations. See Fig. 2 for colour labels. 
area with copious rainfall, whereas to the south the climate is semi-arid with low precipitation. The six sampled rivers are permanent and belong to two drainage systems of the Alborz Mountains: two rivers (Darakeh and Jajrood) form part of the Namak Lake drainage and drain southward towards the centre of Iran, whereas the other four sampled rivers (Taleghan, Sepidrood, Mollali and Arpachai) belong to the South Caspian watershed and drain into the Sepidrood River which finally discharges northward into the Caspian Sea (Fig. 1). A total of 61 specimens of Potamon elbursi were collected during three field trips in 2009 and 2010. One walking leg from each individual was removed and preserved in absolute ethanol. The detailed sampling sites and sample sizes are shown in Tab. 1.

Genomic DNA was isolated from the muscle tissue of walking legs using a modified Puregene method (Gentra Systems) at the University of Regensburg in Germany. DNA from the entire mitochondrial gene cytochrome oxidase subunit I (Cox1, 1500 basepairs) was amplified with the primer combination COL6 (5'-TYTCHACAAAYCATAAAGAYATYGG-3') and COH16 (5'CATYWTTCTGCCATTTTAGA-3') (Schubart, 2009). Polymerase chain reaction (PCR) was carried out under the following conditions: an initial denaturation step at $94^{\circ} \mathrm{C}$ for 4 min prior to 40 cycles consisting of a denaturation step at $95^{\circ} \mathrm{C}$ for $45 \mathrm{~s}$, an annealing step of $45 \mathrm{~s}$ with a touchdown procedure (gradually lowering the annealing temperature from $53^{\circ} \mathrm{C}$ to $50^{\circ} \mathrm{C}$ for the 15 first cycles, followed by 25 cycles with $50^{\circ} \mathrm{C}$ ), an extension step at $72^{\circ} \mathrm{C}$ for $90 \mathrm{~s}$; a final extension at $72^{\circ} \mathrm{C}$ was run for $8 \mathrm{~min}$. Sanger sequencing was outsourced to LGC Genomics (Berlin, Germany) using $\mathrm{COH} 16$ as sequencing primer. The resulting DNA-sequences were manually corrected with Chromas Lite 2.01 (Technelysium Pty Ltd., 2007) and aligned using BioEdit (version 5.09; Hall, 2001). The software Artemis (ver. 14.2.2; Carver et al., 2012) was used to detect possible amplification of pseudogenes. Sequences were submitted to the European Molecular Biological Laboratories database (EMBL) under the accession numbers: LN833869-LN833879.

\section{Statistical analyses}

Haplotype diversities $\left(\mathrm{H}_{\mathrm{d}}\right)$, number of segregating sites (S) and nucleotide diversities $(\pi)$ (Nei, 1987) were computed using DnaSP 5.00 (Librado and Rozas, 2009). The existence of population structure was assessed applying a one-way AMOVA (Excoffier et al., 1992), as implemented in Arlequin ver. 3.5.1.2 (Excoffier and Lischer, 2010). $\Phi_{S T}$ values (Wright, 1951) were calculated based on haplotypic diversity values. The significance levels of pairwise $\Phi_{S T}$ under the null hypothesis of no differentiation between pairs of populations were tested using a nonparametric permutation approach (10,000 permutations of haplotypes among populations; Excoffier et al., 1992). Additionally, a two-way AMOVA was applied pooling populations belonging to the same drainage system.

A statistical parsimony network analysis was conducted using the program TCS ver. 1.21 (Clement et al., 2000). To test historical demographic trends in the metapopulation an overall mismatch distribution was also plotted using Arlequin. Finally, Harpending's raggedness index (Hri; Harpending, 1994) was estimated according to the mismatch distribution. The expansion parameters Tau $(\tau)$, Theta $0(\theta 0)$ and Theta $1(\theta 1)$ were estimated both under a demographic and a spatial expansion hypothesis by a generalized non-linear least-square approach (Schneider and Excoffier, 1999). Li's formula $(t=\tau / 2 \mu$ : $\mathrm{Li}$, 1977) was used to estimate the time (t) at which the demographic or spatial expansion began. The mutation rate $(\mu)$ for Cox 1 was calculated with $2.33 \%$ per million years (Schubart et al., 1998). Approximate confidence intervals for the demographic parameters were obtained by 1000 parametric bootstrap replicates.

\section{RESULTS}

A partial segment of the 3' end of the Coxl gene with readable sequence lengths of at least 840 basepairs (bp) was obtained for the 61 specimens. The sequence alignment was unambiguous and free of stop codons and indels according to the software Artemis, which makes the inclusion of pseudogenes unlikely. The final alignment included 15

Tab. 1. Coordinates, sample size (n), number of haplotypes $(\mathrm{Hn})$, haplotype diversity $\left(\mathrm{H}_{\mathrm{d}}\right)$, and nucleotide diversity $(\pi$, values shown in percentage) for populations from each river.

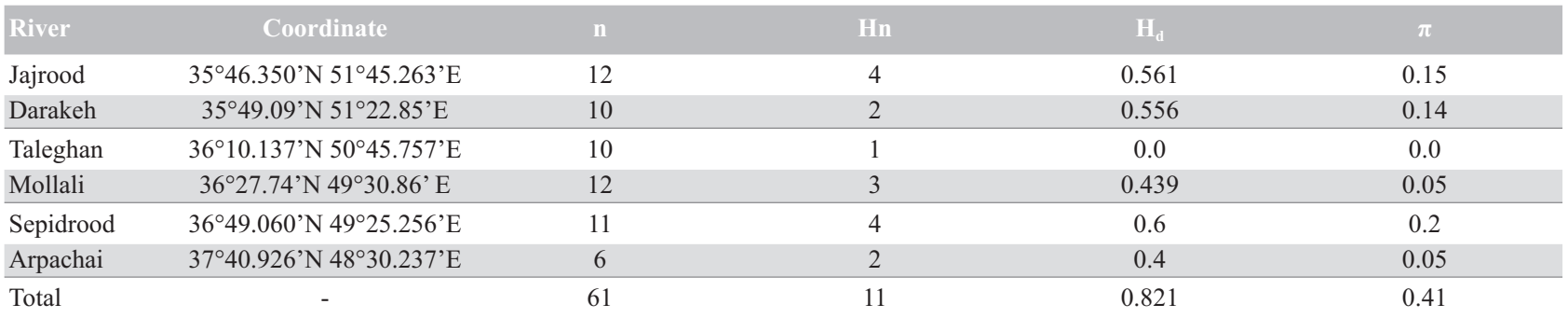


variable sites, of which eleven were parsimony-informative and four were singleton variable sites.

Total haplotype diversity was relatively high (0.821), despite the fact that one population (Taleghan) had only one haplotype. In contrast, total nucleotide diversity was relatively low $(0.41 \%)$, as the eleven detected haplotypes are closely related. Most specimens (42) had one out of three main haplotypes (Fig. 2; haplotypes T, M, P), and the remaining individuals contributed eight additional haplotypes with low frequencies. Among those, four haplotypes were found in single specimens (Tab. 1, Fig. 2).

F-statistics showed an overall significant genetic differentiation among populations $\left(\Phi_{\mathrm{st}}=0.77\right.$, across all samples). All pairwise differences between populations were significant, except for the comparison between populations Sepidrood and Jajrood, belonging to different river systems, with a $\Phi$ st value close to zero (Tab. 2 ). The pop- ulations Taleghan and Darakeh, geographically located in between them, were genetically more distinct, but shared haplotypes with both populations. A two-way AMOVA, grouping populations belonging to the same river basin, indicated that genetic partitioning was not associated with drainage systems $(\Phi \mathrm{ct}=0.293 ; \mathrm{P}=0.199)$.

The shape of the haplotype network was defined by the existence of three main haplotypes (T, M, and P) and clearly indicated an association among haplotypes and locations in line with the AMOVA test. Some haplotypes (i.e., $\mathrm{M}$ and $\mathrm{P}$ ) occurred in more than one population, but a clear genetic partitioning among drainage systems did not emerge. Two populations consisted exclusively of private haplotypes (Mollali and Arpachai, Fig. 2). The populations Jajrood and Sepidrood harboured a total of four different haplotypes, of which three were shared by individuals of both populations, even though they did not be-

Tab. 2. Pairwise $\Phi$ st values of genetic differentiation among populations. Below diagonal are values of $\Phi$ st, and their levels of significance are above diagonal.

\begin{tabular}{|c|c|c|c|c|c|c|}
\hline & Jajrood & Darakeh & Taleghan & Mollali & Sepidrood & Arpachai \\
\hline Jajrood & - & $*$ & * & * & NS & $*$ \\
\hline Darakeh & 0.29 & - & $*$ & $*$ & * & $*$ \\
\hline Taleghan & 0.83 & 0.88 & - & $*$ & $*$ & $*$ \\
\hline Mollali & 0.83 & 0.87 & 0.79 & - & $*$ & $*$ \\
\hline Sepidrood & 0.00 & 0.26 & 0.74 & 0.77 & - & $*$ \\
\hline Arpachai & 0.82 & 0.86 & 0.96 & 0.90 & 0.76 & - \\
\hline
\end{tabular}

$* P<0.01 ;$ NS, not significant.

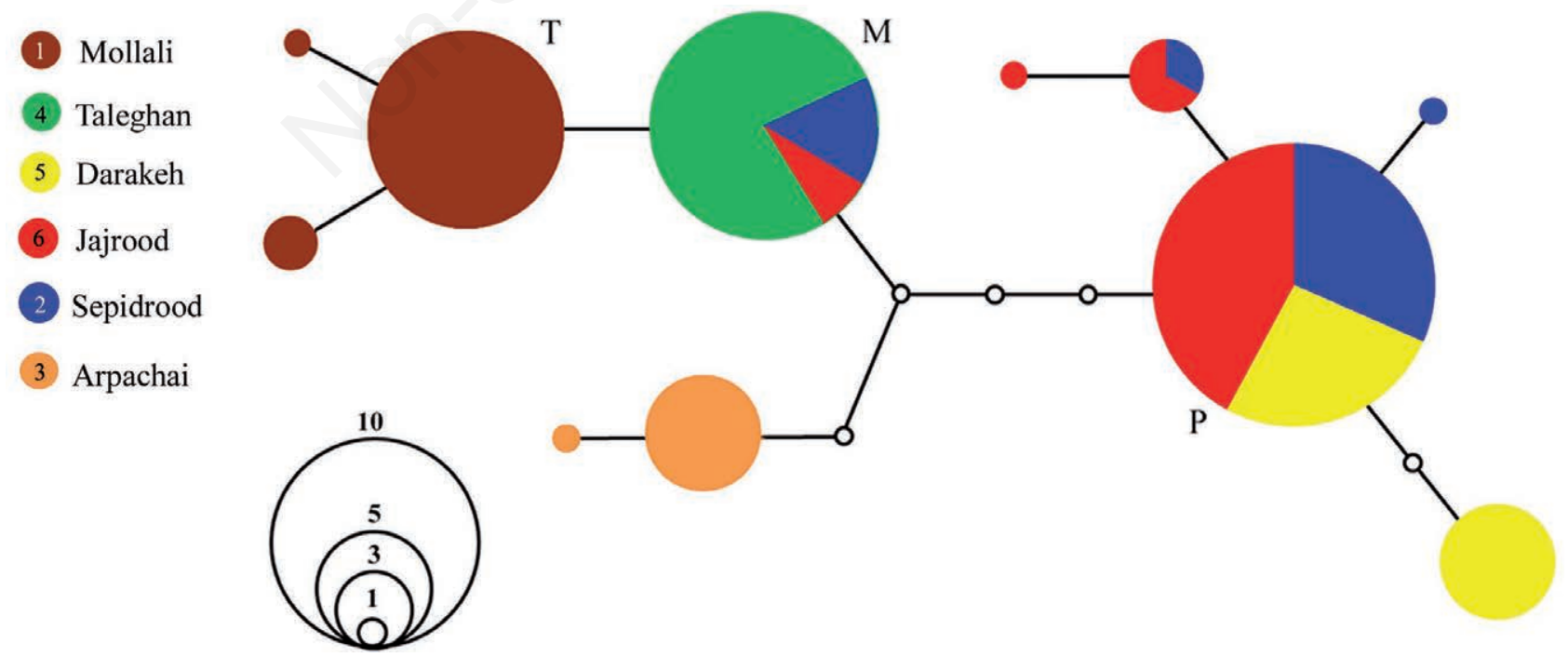

Fig. 2. Maximum parsimony spanning network constructed with TCS based on an 840 basepair alignment of the Cox 1 gene for a total of 61 specimens. Each line represents one substitution, and open circles on lines indicate unsampled haplotypes. The three most common haplotypes are named with the letters M, P, T. The open circles with numbers above indicate the correlation of circle size with number of individuals in each haplotype. Numbers inside the colour labels correspond to haplotype numbers used in Fig. 1. 
long to the same drainage system. The main shared haplotype (haplotype P, see Fig. 2) was also present in the Darakeh population, which belongs to the same drainage system as the Jajrood population. All tested individuals of the population Taleghan revealed the same haplotype (haplotype M, see Fig. 2) which was also occasionally shared with Sepidrood and Jajrood populations.

The skewed unimodal shape of the mismatch distribution and the non-significant value of the raggedness index $(\mathrm{p}=0.035)$ indicate that the null hypothesis of a population out of equilibrium can not be rejected for the metapopulation (Fig. 3). Under the assumption of a demographic expansion, the value for the whole Alborz populations is 5.50 ( $95 \%$ confidence interval: 0.52-9.68), corresponding to a population expansion which began at around 1.2 Mya, while under the spatial expansion hypothesis the value of $\tau$ is 3.82 (95\% confidence interval: $0.88-8.2$ ), corresponding to an expansion time of approximately 0.8 Mya.

\section{DISCUSSION}

This study is the first to document intraspecific genetic differentiation in an organism from the macrozoobenthos of the Alborz Mountains. Our results show that the populations of $P$. elbursi are genetically structured, with the existence of locally private haplotypes in two out of six populations. This finding is perfectly in line with the reproductive biology and limited dispersion ability of freshwater crabs, since they are known to be highly philopatric (i.e., individuals remaining or returning to their point of origin or birthplace) and mostly confined to their provenance freshwater systems (e.g., Daniels et al., 2006 for Potamonautidae). They have also direct development resulting in extended maternal care $(\mathrm{Ng}, 1988)$. In consequence, they can be considered low dispersal organisms, having a limited tendency or ability to cross terrestrial distances between rivers.

Occasionally, freshwater crabs may cross short land bridges during periods of heavy rainfall, when headwaters of these populations originate from the same mountain regions (Daniels, 1998, 2006; Cook et al., 2008; Poettinger et al., 2011; Schubart et al., 2011; Keikhosravi and Schubart, 2014; Schubart and Santl, 2014). Assuming that P. elbursi disperses by walking in the vicinity of rivers, we would have expected more genetic homogeneity in nearby populations of the two different drainage systems (i.e., Jajrood and Taleghan) and among populations of the same river system (e.g., Taleghan and Mollali), because this dispersal favours gene flow among geographically close and connected rivers. Instead, the genetic partitioning we recorded did not appear to match up with the drainage systems (e.g., the Caspian and Namak Lake drainages), as can be seen in the haplotype network and the $\Phi$ ct value. More- over, based on the $\Phi$ st pairwise comparisons, we found that the only two populations not genetically differentiated from each other (Jajrood and Sepidrood) belong to different drainage systems and are geographically distant. This unexpected result could be due to incomplete lineage sorting, which is not a rare event in animals (Funk and Omland, 2003), or alternatively due to human translocation events, commonly recorded for freshwater crustaceans (Charmantier, 1992; Fratini et al., 2005; Noël and Guinot, 2007; Jesse et al., 2009).

The populations of Mollali and Arpachai had their own private haplotypes and thus appear totally genetically isolated from all other populations. This could be explained by the three following factors, singularly or in concert: the first is a recent population expansion following a low effective population size caused by bottlenecks (Hou et al., 2012); the second is proneness of small populations to genetic drift, as a consequence of founder effects under a reduced gene flow and population size model (Whiteley et al., 2004); and the third is regional philopatric behaviour of freshwater crabs. Further studies, based on an extended dataset and on nuclear markers (i.e., microsatellites), are needed in order to decide which of these factors played a decisive role in forming the current population structure.

In the present case of the freshwater crab P. elbursi, the metapopulation carries the signature of population bottlenecks occurring in the recent past. This is revealed by the

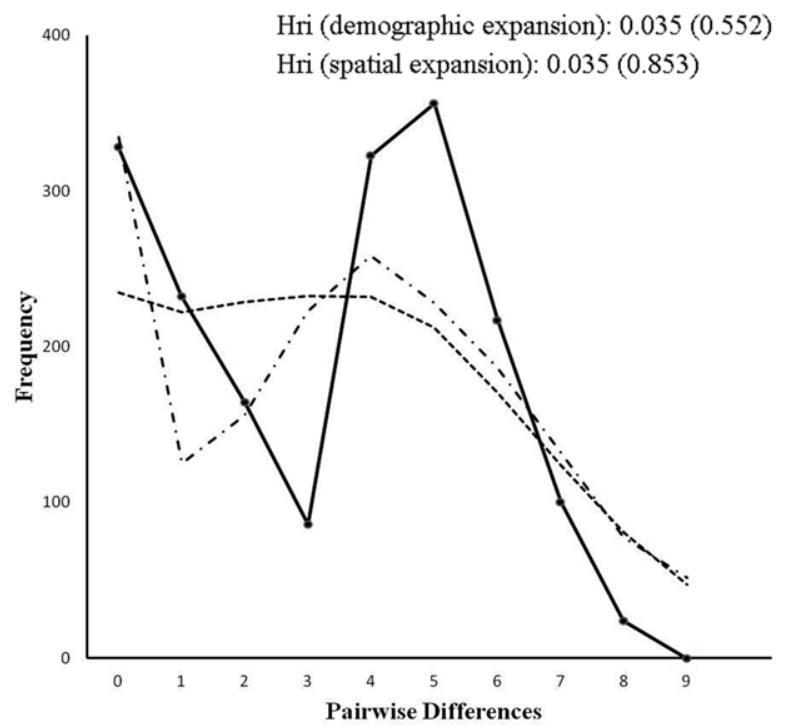

Fig. 3. Mismatch distribution of the whole dataset. Dotted line represents expected value under the hypothesis of spatial expansion; dashed line indicates expected value under the hypothesis of demographic expansion; solid lines represent the observed data. Hri, Harpending's raggedness index; P-values are provided in brackets. 
unimodal shape of the mismatch distribution as well as the non-significant value of the raggedness index (Fig. 3). In addition, the result of the mismatch distribution is in line with the overall high haplotype diversity $\left(\mathrm{H}_{\mathrm{d}}=0.82\right)$ and low nucleotide diversity $(\pi=0.41 \%)$ as well as with the shape of the haplotype network (Fig. 2; Tab. 1). Our calculated time frame for the presumed expansion events suggests a Pleistocene context: the last P. elbursi population expansion seems in fact to have occurred around $1 \mathrm{My}$ ago. This dating is highly plausible, since climatic fluctuations during the Pleistocene are known to have affected the population structure and distribution of other species inhabiting the Alborz Mountains (Veith et al., 2003) as well as favouring speciation processes in this area (Brandis et al., 2000).

\section{CONCLUSIONS}

The restricted distributions of most of the freshwater crab species pose serious problems for conservation issues (Yeo et al., 2008). Potamon elbursi is represented in both of the local basins sampled, Namak Lake and South Caspian Sea in Iran. The sampling trips between 2009 and 2010 for this study revealed that both watersheds limiting the distribution of $P$. elbursi are suffering heavily from desiccation and dam construction. In addition, this freshwater crab, as well as the rest of the local macrozoobenthos, has not received any conservation attention. These factors combined justify a prompt and thorough investigation of this species' populations with a wider sampling strategy and possibly conservation efforts.

\section{ACKNOWLEDGMENTS}

The authors would like to express their special appreciation to Yadollah and Fatollah Houshmand who helped to collect specimens. Special thanks go to Nicole Rivera for her great help with statistical analysis and to Tomer Czaczkes for English proofreading. Our thanks also go to Prof. Jürgen Heinze (University of Regensburg) and his staff for the use of the necessary facilities and continuing support and the Akademisches Auslandsamt of the University of Regensburg for financial support.

\section{REFERENCES}

Ahmadzadeh F, Carretero MA, Rödder D, Harris DJ, Freitas SN, Perera A, Böhme W, 2012. Inferring the effects of past climate fluctuations on the distribution pattern of Iranolacerta (Reptilia, Lacertidae): evidence from mitochondrial DNA and species distribution models. Zool. Anz. 252:141-148.

Avise JC, 2000. Phylogeography: the history and formation of species. Harvard University Press, Cambridge: $447 \mathrm{pp}$.

Banarescu P, 1991. Zoogeography of freshwaters. 1. General distribution and dispersal of freshwater animals. AULA-Verlag, Wiesbaden: $511 \mathrm{pp}$.

Brandis D, Storch V, Türkay M, 2000. Taxonomy and zoogeography of the freshwater crabs of Europe, North Africa, and the Middle East. Senckenbergiana Biologica 80:5-56.

Carver T, Harris SR, Berriman M, Parkhill J, McQuillan JA, 2012. Artemis: an integrated platform for visualization and analysis of high-throughput sequence-based experimental data. Bioinformatics 28:464-469.

Charmantier G, 1992. Occurence of freshwater crabs, genus Potamon, in southern France. J. Crustacean Biol. 12:620-626.

Clement M, Posada D, Crandall KA, 2000. TCS: a computer program to estimate gene genealogies. Mol. Ecol. 9:1657-1659.

Coad B, 1980. Environmental change and its impact on the freshwater fishes of Iran. Biol. Conserv. 19:51-80.

Cook BD, Pringle CM, Hughes JM, 2008. Phylogeography of an island endemic, the Puerto Rican freshwater crab (Epilobocera sinuatifrons). J. Hered. 99:157-164.

Cumberlidge N, Ng PKL, Yeo DCJ, Magalhaes C, Campos MR, Alvarez F, Naruse T, Daniels SR, Esser LJ, Attipoe FYK, Clotilde-Ba FL, Darwall W, McIvor A, Baillie JEM, Collen B, Ram M, 2009. Freshwater crabs and the biodiversity crisis: importance, threats, status, and conservation challenges. Biol. Conserv. 142:1665-1673.

Daniels SR, Gouws G, Crandall KA, 2006. Phylogeographic patterning in a freshwater crab species (Decapoda: Potamonautidae: Potamonautes) reveals the signature of historical climatic oscillations. J. Biogeogr. 33:1538-1549.

Daniels SR, Stewart BA, Gibbons MJ, 1998. Genetic and morphometric variation in the potamonautid river crab Potamonautes parvispina (Decapoda: Potamonautidae) from two Western Cape rivers, South Africa. J. Nat. Hist. 32:1245-1258.

Excoffier L, Lischer HEL, 2010. Arlequin suite ver 3.5: a new series of program perform population genetics analyses under Linux and Windows. Mol. Ecol. Resour. 10:564-567.

Excoffier L, Smouse PE, Quattro JM, 1992. Analysis of molecular variance inferred from metric distances among DNA haplotypes: application to human mitochondrial DNA restriction data. Genetics 131:479-491.

Fratini S, Zaccara S, Barbaresi S, Grandjean F, Souty-Grosset C, Crosa G, Gherardi F, 2005. Phylogeography of the threatened crayfish (genus Austropotamobius) in Italy: implications for its conservation. Heredity 94:108-118.

Funk DJ, Omland KE, 2003. Species-level paraphyly and polyphyly: frequency, causes, and consequences, with insights from animal mitochondrial DNA. Annu. Rev. Ecol. Evol. Syst. 34:397-423.

Hall TA, 2001. BioEdit: a user-friendly biological sequence alignment editor and analysis, ver. 5.09. Department of Microbiology, North Carolina State University.

Harpending HC, 1994. Signature of ancient population growth in a low-resolution mitochondrial DNA mismatch distribution. Hum. Biol. 66:591-600.

Hewitt G, 2000. The genetic legacy of the Quaternary ice ages. Nature 405:907-913.

Hou F, Zhang X, Zhang X, Yue B, Song Z, 2012. High intrapopulation genetic variability and inter-population differentiation in a plateau specialized fish, Triplophysa orientalis. Environ. Biol. Fish. 93:519-530.

Jesse R, Pfenninger M, Fratini S, Scalici M, Streit B, Schubart $C D, 2009$. Disjunct distribution of the Mediterranean freshwater crab Potamon fluviatile - natural expansion or human introduction? Biol. Invasions 10:2209-2221.

Keikhosravi A, Schubart CD, 2014. Revalidation and redescrip- 
tion of Potamon elbursi Pretzmann, 1976 (Brachyura, Potamidae) from Iran, based on morphology and genetics. Cent. Eur. J. Biol. 9:114-123.

Kiabi BH, Abdoli A, Naderi M, 1999. Status of the fish fauna in the South Caspian Basin of Iran. Zool. Middle East 18:57-65.

Krinsley DB, 1968. Geomorphology of three kavirs in northern Iran, p. 105-130. In: J.T. Neal (ed.), Playa surface morphology: miscellaneous investigations. U.S. Air Force, Office of Aerospace Research.

Li WH, 1977. Distribution of nucleotide differences between two randomly chosen cistrons in a finite population. Genetics 85:331-337.

Librado P, Rozas J, 2009. DnaSP v5: a software for comprehensive analysis of DNA polymorphism data. Bioinformatics 25:1451-1452.

Nei M, 1987. Molecular evolutionary genetics. Columbia University Press, New York: 512 pp.

$\mathrm{Ng}$ PKL, 1988. The freshwater crabs of Peninsular Malaysia and Singapore. Shing Lee Publ., Singapore: 156 pp.

Noël P, Guinot D, 2007. Non-indigenous freshwater crabs in France: a new occurrence of a potamid near Nice, p. 77-90. In: F. Gherardi (ed.), Invasion ecology of biological invaders in inland waters: profiles, distribution, and threats. Springer.

Poettinger T, Wehrtmann IS, Schubart CD, 2011. [Genfluss in Flussoberläufen des zentralen Hochlands von Costa Rica? Vorläufige Ergebnisse bei Süßwasserkrabben (Pseudothelphusidae), p. 242-246].[Article in German]. Proceedings of the Deutsche Gesellschaft für Limnologie Annual Meeting 2010, Hardegsen, Germany.

Rajaei Sh H, Rödder D, Weigand AM, Dambach J, Raupach MJ, Wägele JW, 2013. Quaternary refugia in southwestern Iran: insights from two sympatric moth species (Insecta, Lepidoptera). Org. Divers. Evol. 13:1-15.

Schneider S, Excoffier L, 1999. Estimation of past demographic parameters from the distribution of pairwise differences when the mutation rates vary among sites: application to human mitochondrial DNA. Genetics 152:1079-1089.
Schubart CD, Diesel R, Hedges SB, 1998. Rapid evolution to terrestrial life in Jamaican crabs. Nature 393:363-365.

Schubart CD, 2009. Mitochondrial DNA and decapod phylogenies; the importance of pseudogenes and primer optimization, p. 47-65. In: J.W. Martin, K.L. Crandall and D.L. Felder (eds.), Crustacean Issues 18: Decapod Crustaceans Phylogenetics. Taylor \& Francis CRC Press, Boca Raton.

Schubart CD, Rivera NT, Crandall KA, Santl T, 2011. Shallow phylogeographic structure of Puerto Rico freshwater crabs: an evolutionary explanation for low species diversity compared to Jamaica, p. 352-365. In: C. Held, S. Koenemann and C.D. Schubart (eds.), Crustacean Issues 19: Phylogeography and Population Genetics in Crustacea. Taylor \& Francis CRC Press, Boca Raton.

Schubart CD, Santl T, 2014. Differentiation within a river system: ecology or geography driven? Evolutionary significant units and new species in Jamaican freshwater crabs, p. 173193. In: D.C.J. Yeo, N. Cumberlidge and S. Klaus (eds.), Crustaceana Monogrphs 19: advances in freshwater decapod systematics and biology. Brill Publ., Leiden.

Technelysium Pty Ltd. 2007. Chromas lite ver. 2.01. Available from: http://www.technelysium.com.au/chromas_lite.html

Veith M, Schmidtler J, Kosuch J, Baran I, Seitz A, 2003. Palaeoclimatic changes explain Anatolian mountain frog evolution: a test for alternating vicariance and dispersal events. Mol. Ecol. 12:185-199.

Whiteley AR, Spruell P, Allendorf FW, 2004. Ecological and life history characteristics predict population genetic divergence of two salmonids in the same landscape. Mol. Ecol. 13: 3675-3688.

Wright S, 1951. The genetical structure of populations. Annual Eugenics 15:323-354.

Yeo DCJ, Ng PKL, Cumberlidge N, Magalhães C, Daniels SR, Martha R, 2008. Global diversity of crabs (Crustacea: Decapoda: Brachyura) in freshwater. Hydrobiologia 595: 275-286. 